\title{
Unusual cause of mediastinal mass
}

\author{
Smita Manchanda, Ashu Bhalla, Priyanka Naranje
}

Department of Radiodiagnosis, All India Institute of Medical Sciences, New Delhi, India

\section{Correspondence to} Dr Smita Manchanda, smitamanchanda@gmail.com

Accepted 27 April 2017

\section{DESCRIPTION}

A 35-year-old asymptomatic man presented for chest radiograph evaluation as a part of pre-employment medical examination. The radiograph revealed a large, dense homogenous mass with sharply defined margins and a broad base towards the mediastinum overlying the right hilum. There was also evidence of linear calcification along the right paramediastinal stripe (figure 1). A probable diagnosis of mediastinal mass was made and the patient was advised contrast-enhanced computed tomography of the chest. CT revealed plaque-like calcification of the pleura posteriorly along the chest wall. There was no associated mass lesion in the mediastinum or lung parenchyma (figure 2). Patient gave history of antituberculosis treatment for right empyema 5 years ago. A diagnosis of pleural calcification as sequelae of healed empyema was made.

Unilateral pleural calcification is usually seen in cases of healed empyema or haemothorax. There is associated visceral pleural thickening and calcification is typically seen along the inner aspect of this thickening. ${ }^{1}$ Other causes of diffuse pleural thickening include asbestosis, pulmonary fibrosis, irradiation, previous surgery and drugs. ${ }^{2}$ In asbestosis characteristically the parietal pleura is thickened and plaques are seen along the chest wall, diaphragm or cardiac border. ${ }^{1}$

On plain radiographs, pleural calcification is typically linear in appearance when seen in profile (the lateral view in this case) ${ }^{3}$ and sheet-like or
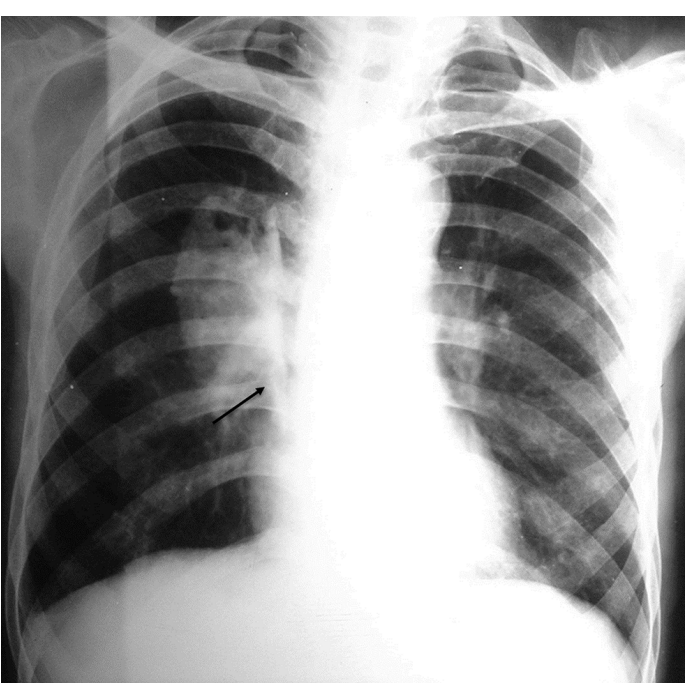

Figure 1 Chest radiograph reveals a large, dense homogenous mass with sharply defined margins and a broad base towards the mediastinum overlying the right hilum with linear calcification (arrow) along the right paramediastinal stripe.

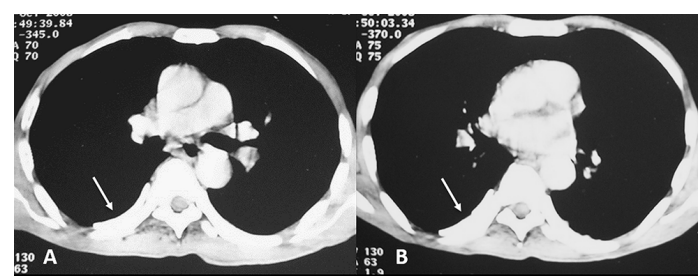

Figure 2 ( $A, B)$ Contrast-enhanced computed tomography chest axial sections show plaque-like calcification of the pleura posteriorly along the chest wall (arrows in A and B). There is no associated mass lesion in the mediastinum or lung parenchyma.

plaque-like in the enface view (the frontal radiograph in this case). ${ }^{1}$ It is also important to remember that for pleural calcifications in the anterior or posterior chest wall, the frontal radiograph is the enface view and the lateral radiograph is the profile view whereas it is the reverse for pleural calcifications in the lateral chest wall. This sheet-like morphology in the enface view can occasionally appear as a dense homogenous mass and may mimic a mediastinal or parenchymal pathology (as was seen in this case). The key identification points are the relatively high density, sheet-like appearance and sharp margins of pleural calcification.

\section{Learning points}

- Pleural calcification has a linear appearance in the profile view and sheet-like or plaquelike morphology in the en face view in a plain radiograph.

- Presence of relatively high-density, sheetlike appearance and sharp margins of any suspected mass on plain radiograph should alert the clinician for possible pleural pathology.

Contributors SM: literature search, manuscript preparation and editing. $A B$ and $P N$ : manuscript editing and contribution to figures. Competing interests None declared.

Patient consent Obtained.

Provenance and peer review Not commissioned; externally peer reviewed.

(c) BMJ Publishing Group Ltd (unless otherwise stated in the text of the article) 2017. All rights reserved. No commercial use is permitted unless otherwise expressly granted.

\section{REFERENCES}

1 Bendayan D, Barziv Y, Kramer MR. Pulmonary calcifications: a review. Respir Med 2000;94:190-3.

2 Sureka B, Thukral BB, Mittal MK, et al. Radiological review of pleural tumors. Indian J Radiol Imaging 2013;23:313-20.

3 Elshazley M, Shibata E, Hisanaga N, et al. Pleural plaque profiles on the chest radiographs and CT scans of asbestos-exposed Japanese construction workers. Ind Health 2011;49:626-33. 
Copyright 2017 BMJ Publishing Group. All rights reserved. For permission to reuse any of this content visit http://group.bmj.com/group/rights-licensing/permissions.

BMJ Case Report Fellows may re-use this article for personal use and teaching without any further permission.

Become a Fellow of BMJ Case Reports today and you can:

- Submit as many cases as you like

- Enjoy fast sympathetic peer review and rapid publication of accepted articles

Access all the published articles

- Re-use any of the published material for personal use and teaching without further permission

For information on Institutional Fellowships contact consortiasales@bmjgroup.com

Visit casereports.bmj.com for more articles like this and to become a Fellow 